\title{
Pengembangan Media Pembelajaran Matematika Berbasis Konstruktivisme pada Materi Segitiga Siswa Kelas VII SMP
}

\author{
Elsi Indria Sari ${ }^{1}$, Nizlel Huda ${ }^{2}$, Syamsurizal ${ }^{3}$ \\ ${ }_{1,2}$ Program Studi Pendidikan Matematika, Fakultas Keguruan dan Ilmu Pendidikan, Universitas Jambi, \\ Jl. Raden Mattaher No 21, Jambi, Indonesia \\ indriaelsi@gmail.com
}

\begin{abstract}
This research is a development research using the 4-D model. This model consists of the stages of defining, designing, developing and disseminating. The define stage includes needs analysis, curriculum analysis, student characteristic analysis, and analysis of existing learning media. At the design stage, the design and preparation of material on the media was carried out using the Macromedia Flash 8 program. In the development stage, validation tests were carried out by mathematical experts, multimedia experts and language experts as well as practicality and effectiveness tests of macromedia flash 8 media by mathematics teachers and students through limited trials. The dissemination stage is limited to students who are the subject of the trial. Data on the practicality of the media were obtained from individual trial questionnaires and the results of observations of the implementation of learning, while the effectiveness data were obtained from the questionnaires given to students through small group trials, large group trials, and the results of interviews with teachers and students. The collected data were analyzed descriptively.
\end{abstract}

Keywords: Macromedia Flash, Learning Media, Mathematics Learning.

\begin{abstract}
Abstrak
Penelitian ini merupakan penelitian pengembangan yang menggunakan model 4-D. Model ini terdiri daritahap pendefinisian (define), perancangan (design), pengembangan (develop) dan penyebaran (disseminate). Tahap define meliputi analisis kebutuhan, analisis kurikulum, analisis karakteristik siswa, dan analisis media pembelajaran yang telah ada. Pada tahap design dilakukan perancangan dan penyusunan materi pada media menggunakan program Macromedia Flash 8. Padatahap develop dilakukan uji validasi oleh pakar matematika, pakar multimedia dan pakar bahasa serta uji praktikalitas dan uji efektivitas media macromedia flash 8 oleh guru matematika dan siswa melalui uji coba terbatas. Untuk tahap disseminate dilakukan secara terbatas kepada siswa yang menjadi subjek uji coba. Data praktikalitas media diperoleh dari angket uji coba perorangan serta hasil obervasi keterlaksanaan pembelajaran, sedangkan data efektivitas diperoleh dariangket yang diberikan kepada siswa melalui uji coba kelompok kecil, uji coba kelompok besar, serta hasil wawancara dengan guru dan siswa. Data yang terkumpul dianalisis secara deskriptif. Kata kunci: Macromedia Flash, Media Pembelajaran, Pembelajaran Matematika
\end{abstract}

Copyright (c) 2021 Elsi Indria Sari, Nizlel Huda, Syamsurizal

$\triangle$ Corresponding author: Elsi Indria Sari

Email Address: indriaelsi@gmail.com (Jl. Raden Mattaher No 21, Jambi, Indonesia)

Received 22 April 2021, Accepted 29 Mei 2021, Published 24 Juni 2021

\section{PENDAHULUAN}

Dalam memasuki perkembangana zaman saat ini yang serba modern, sistem pendidikan Nasional menghadapi tantangan yang sangat kompleks dalam menyiapkan kualitas Sumber Daya Manusia (SDM) yang mampu bersaing di era global. Upaya tepat untuk menyiapkan Sumber Daya Manusia (SDM) yang berkualitas dan satu-satunya wadah yang dapat dipandang dan dapat berfungsi membangun SDM yang bermutu tinggi dengan kualitas pendidikan yang baik.

Masalah utama dalam pembelajaran pada pendidikan formal (sekolah) pada zaman ini adalah masih rendahnya perhatian siswa dalam proses pembelajaran, ini tentunya merupakan hasil kondisi pembelajaran yang masih bersifat konvensional dan tidak menyentuh ranah dimensi siswa itu sendiri, yaitu bagaimana 
sebenarnya belajar itu. Proses pembelajaran didominasi guru dan tidak memberikan akses bagi anak didik untuk berkembang secara mandiri melalaui penemuan dalam proses berfikirnya.

Beberapa tahun ini kita menerapkan kurikulum baru yakni kurikulum 2013. Penerapan kurikulum baru ini di sekolah yang sebagaimana kita ketahui menuntut pelaksana pembelajaran berbasis komputer atau TIK diperlukan sebuah cara untuk membuat sebuah pelaksanaan pembelajaran. Untuk itu harus diciptakan situasi dan kondisi kelas yang kondusif agar proses belajar mengajar dapat berlangsung sesuai dengan tujuan yang diharapkan, tidak hanya sekedar menghafal tapi siswa dituntun untuk membangun konsep didalam dirinya sehingga pembelajaran bermakna bagi siswa. Pada kenyataannya apa yang diterapkan guru jauh dari tujuan pembelajaran yang diharapkan kurikulum.

Guru selalu memulai tujuan pembelajaran dengan sesuatu yang formal seperti rumus-rumus dan siswa dipaksa menghafal konsep matematika. Pembelajaran konvensional masih banyak diterapkan di kelas-kelas, guru menjadi pusat dan sumber belajar bagi siswa, sedangkan siswa hanya pasif menunggu transfer pengetahuan dari guru. Padahal faktor guru sangat besar pengaruhnya terhadap keberhasilan proses pembelajaran yang dilakukannya (Barlia, 2010). Dari beberapa kenyataan di lapangan diperlukan suatu perubahan agar pembelajaran menjadi bermakna bagi siswa sehingga mereka dapat mengaplikasikan ilmu yang mereka dapat dalam kehidupannya. Untuk itu diperlukan suatu pendekatan pembelajaran yang membantu guru mengaitkan antara materi yang diajarkannya dengan situasi dunia nyata siswa dan mendorong siswa membuat hubungan antara pengetahuan yang dimilikinya dengan penerapannya dalam kehidupan mereka sehari-hari. Salah satunya yaitu pembelajaran dengan pendekatan konstruktivisme. Manusia harus mengkonstruksi pengetahuan itu dan memberi makna melalui pengalaman nyata (Trianto, 2009). Menurut Glasersfeld \& Von, 1990, "Pengetahuan merupakan hasil dari aktivitas individu anak itu sendiri, bukan merupakan sesuatu atau komoditas yang berada di luar orang yang mempunyai pengetahuan itu sendiri, dan dapat disampaikan atau di-install oleh persepsi yang masuk akal atau komunikasi bahasa.”

Dalam pembelajaran dengan pendekatan konstruktivisme, siswa dibiasakan memecahkan masalah, menemukan sesuatu. Siswa harus mengkonstruksikan pengetahuan di benak mereka sendiri. Inti dari teori konstruktivis adalah bahwa siswa harus menemukan dan mentransformasikan suatu informasi. Konstruktivisme dibedakan menjadi dua yaitu konstruktivisme personal (Piaget 1981) dan konstruktivisme sosial (Vygotsky) (Adisusilo, 2012). Konstruktivisme adalah aliran filsafat pengetahuan yang berpendapat bahwa pengetahuan (knowledge) merupakan hasil konstruksi (bentukan) dari seorang yang sedang belajar. Maksudnya setiap orang membentuk pengetahuannya sendiri (Kukla, 2003). Untuk itu dalam proses pembelajaran harus dapat memfasilitasi proses tersebut dengan menjadikan pengetahuan bermakna dan relevan bagi siswa dan menyadarkan siswa agar menerapkan strategi mereka sendiri dalam belajar, namun hal itu belum terpenuhi karena guru juga tidak pernah mengaitkan apa yang dipelajari siswa dengan kehidupan sehari-hari sehingga pembelajaran menjadi tidak bermakna.

Ariesto, (2008) mengungkapkan bahwa macromedia flash adalah salah satu authoring tool untuk produksi multimedia dan internet, macromedia flash tidak hanya menggabungkan elemen multimedia ke dalam portable movie, tetapi disamping itu dengan Action Script, macromedia flash mempunyai 
Pengembangan Media Pembelajaran Matematika Berbasis Konstruktivisme pada Materi Segitiga Siswa Kelas VII SMP, Elsi Indria Sari, Nizlel Huda, Syamsurizal

kemampuan dalam interactive scripting. macromedia flash merupakan software animasi yang dapat membantu dalam memvisualkan materi pelajaran dalam bentuk animasi pelajaran interaktif sehingga membantu siswa dalam mengkonstruksi konsep (Priyanto, 2017). Prosedur pengembangan program macromedia flash ini menggunakan model 4-D yang dikemukakan oleh Thiagarajan et.al., (1974). Model ini terdiri dari 4 tahap, yaitu tahap pendefinisian (define), tahap perancangan (design), tahap pengembangan (develop), dan tahap penyebaran (disseminate).

\section{METODE}

Jenis penelitian yang digunakan adalah penelitian R \& D (Riset \& Development). Penelitian ini merupakan penelitian pengembangan yang menggunakan model 4-D. Model ini terdiri daritahap pendefinisian (define), perancangan (design), pengembangan (develop) dan penyebaran.

Produk yang dikembangkan pada penelitian ini adalah hasil macromedia flash 8 matematika dengan pendekatan kontstruktivisme pada materi segitiga yang didesain untuk meningkatkan pemahaman konsep matematika. Menurut Yudhiantoro, (2003) "Flash adalah program untuk menggambar grafis dan animasi yang dipasang pada website. Menurut Anggra (2008), Mcaromedia Flash 8 adalah salah satu versi software dari Macromedia.Inc berupa program grafis dan animasiyang keberadaanya ditujukan bagi pecinta desain dan animasi untuk berkreasi membuat animasi web interaktif, film animasi kartun, pembuatan company profile presentasi bisnis atau kegiatan, dan game flash yang menarik. Program ini berbasis vector grafis, namun demikian juga dapat di isi dengan bitmap yang di impor dari program lain”.Produk yang dikembangkan divalidasi oleh ahli dan praktisi sebelum diujicobakan kepada siswa (Rusdi, 2018). Validasi ahli yang dilakukan pada aspek desain dan materi pembelajaran. Kemudian, validasi praktisi yang dilakukan oleh seorang guru mata pelajaran matematika.

Subjek uji coba pada penelitian ini adalah siswa kelas VII jenjang SMP yang terdiri dari 20 orang. Data yang dikumpulkan pada penelitian ini berupa saran dari validasi ahli dan praktisi, hasil tes siswa setelah uji coba produk, dan persepsi siswa terhadap produk yang diuji cobakan. Uji coba dilakukan dengan meminta siswa melihat dan mendengarkan penjelasan produk dan materi yang dikembangkan dengan pendekatan konstruktivisme. Lerman (1988) dan Glasersfeld \& Von (1990) berpendapat bahwa secara epistemologis, inti konstruktivisme psikologis adalah pengetahuan pada dasarnya dibentuk secara aktif oleh subjek (peserta didik) itu sendiri. Dengan kata lain, pengetahuan tidak secara pasif diterima dari lingkungan. Selanjutnya, dijelaskan juga bahwa mengetahui atau memahami adalah hasil dari proses adaptasi melalui pengorganisasian pengalaman- pengalaman dari lingkungan sekitar. Hal itu berarti, tidak membuka peluang bagi pengalaman-pengalaman sebelumnya yang ada di luar pemikiran (otak) orang yang mengetahui tersebut. Wheatley, (1991) mempunyai pendapat yang sama sehubungan dengan inti epistemologis konstruktivisme. Dia berpendapat bahwa konstruktivisme mempunyai dua prinsip dasar, yaitu pengetahuan tidak diperoleh secara pasif, akan tetapi secara aktif dibentuk oleh manusia itu sendiri.Setelah itu, siswa diberikan instrumen penelitian.

Instrumen penelitian yang digunakan adalah angket terbuka untuk validasi, angket tertutup untuk uji 
coba perorangan, uji coba kelompok kecil dan uji coba kelompok besar dan tes untuk hasil belajar siswa. Angket terbuka adalah angket yang disusun sedemikian rupa sehingga responden bebas mengemukakan pendapat berupa saran dan komentarnya (Sugiyono, 2017). Butir-butir angket terbuka disusun sesuai dengan kriteria perangkat media pembelajaran yang berkualitas yaitu, kualitas isi dan tujuan, kualitas instruksional, dan kualitas teknis (Arsyad, 2011). Angket terbuka dalam penelitian ini terdiri dari 2 macam, yaitu angket validasi desain pembelajaran dan angket validasi materi pembelajaran. Saran dan komentar dari tim validator merupakan data yang menyatakan produk yang dikembangkan layak untuk masuk ke tahap selanjutnya. Angket tertutup adalah pertanyaan atau pernyataan-pernyataan yang telah memiliki alternatif jawaban menggunakan skala penilaian yang dipilih oleh responden (Sugiyono, 2017). Skala penilaian yang digunakan adalah skala likert yang bertujuan untuk mengetahui sejauh mana pendidik dan peserta didik menerima atau menolak pernyataan yang diberikan. Tes untuk hasil belajar siswa berupa soal uraian yang sesuai dengan indikator pemahaman konsep materi perbandingan trigonometri. Setiap soal memiliki bobot yang berbeda dengan mempertimbangkan faktor yang berkaitan materi dan karakteristik soal itu sendiri, seperti ruang lingkup materi yang hendak dibuat soalnya, esensialitas dan tingkat kedalaman materi yang ditanyakan serta tingkat kesukaran soal.

\section{HASIL DAN DISKUSI}

Penelitian ini menggunakan metode penelitian dan pengembangan atau dikenal Research and Development $(R \& D)$. R\&D dalam pendidikan sering kemudian disebut research-based development (Borg \& Gall, 1983) pengembangan berbasis penelitian yaitu proses yang digunakan untuk mengembangkan dan memvalidasi produk-produk pendidikan.

Secara keseluruhan proses pengembangan multimedia pembelajaran matematika yang dilaksanakan oleh peneliti telah sesuai dengan model pengembangan 4-D yaitu Define, Design, Develop dan Desseminate (Trianto, 2009).

Tahap pendefinisian (Define), Trianto, (2009) menyatakan pendefinisian adalah "Menetapkan dan mendefinisikan syarat-syarat pembelajaran"Pertama peneliti melaksanakan analisis kurikulum, kurikulum yang digunakan di SMP adalah Kurikulum K13. Lebih jauh, Driver \& Oldham, (1986), berpendapat bahwa dalam merancang kurikulum berdasarkan prinsip- prinsip konstruktivisme tidak sama dengan kurikulum tradisional yang umumnya biasa kita jumpai saat ini, yaitu: siswa pasif, guru yang aktif. Kedua peneliti melakukan analisis siswa, yaitu siswa kelas VII. Dari hasil analisis siswa diperoleh bahwa siswa kelas VII rata-rata berusia 14-15 tahun.Ketiga peneliti melakukan analisis konsep, analisis konsep disusun berdasarkan silabus yang teperinci mengenai standar kompetensi, kompetensi dasar, dan indokator pencapaian.

Tahap perancangan (Design). Tahap ini adalah tahap pembuatan kerangka penyusunan multimedia pembelajaran matematika yang meliputi design awal multimedia pembelajaran matematika. Dalam design awal peneliti mendesign sampul depan, sampul belakang dan isi multimedia pembelajaran matematika. 
Pengembangan Media Pembelajaran Matematika Berbasis Konstruktivisme pada Materi Segitiga Siswa Kelas VII SMP, Elsi Indria Sari, Nizlel Huda, Syamsurizal

Tahap Pengembangan (Develop). Purwanto, (2004) menyatakan "Untuk mengukur kesesuaian, efisiensi, dan kemantapan suatu alat dipergunakan bermacam-macam kualitas seperti validitas, kepraktisan dan efektifitas". Setelah dihasilkan produk rancangan awal, selanjutnya dilakukan tahap pengembangan.Tahap ini diawali dengan validasi oleh pakar ahli materi dan ahli desain. Apabila belum valid maka direvisi kembali sehingga menghasilkan produk multimedia pembelajaran matematika yang valid, kemudian setelah valid di uji coba tebatas pada siswa SMP untuk menghasilkan produk multimedia pembelajaran matematika yang praktis, apabila belum praktis maka lakukan revisi kembali sehingga multimedia pembelajaran matematika dinyatakan praktis.

Kelayakan multimedia pembelajaran matematika materi segitga diukur menggunakan lembar angket praktikalitas oleh guru dan respon siswa dari uji coba terbatas, maka terciptanya multimedia pembelajaran matematika yang valid dan praktis.

Kualitas media macromedia flash 8 Berbasis konstruktivisme pada Materi segitiga dapat dilihat dari segi kevalidan, kepraktisan dan keefektifan media. Tahap pertama yakni validasi. Validasi yang dilakukan oleh ahli materi dan ahli desain untuk melihat validasi macromedia flash 8 Berbasis konstruktivisme pada Materi segitiga dilihat dari segi materi dan desain. Validasi dilakukan oleh bapak Dr. Kamid, M.Si dan bapak Dr. Syaiful, M.Pd yang merupakan dosen matematika Universitas Jambi. Produk awal yang telah dihasilkan selanjutnya divalidasi oleh tim ahli yaitu ahli media berupa konstruk dan konten guna menilai kelayakan produk yang dikembangkan. Hasil validasi inilah yang dijadikan bahan perbaikan produk. Validator merupakan orang yang memvalidasi produk yang telah dikembangkan oleh peneliti. Menurut pendapat Sugiyono, (2017) menyatakan bahwa "validasi produk dapat dilakukan dengan cara menghadirkan beberapa pakar atau tenaga ahli yang sudah berpengalaman untuk menilai produk baru yang sudah dirancang tersebut".

Berdasarkan hasil validasi materi dan desain pembelajaran oleh tim ahli dinyatakan bahwa macromedia flash 8 Berbasis konstruktivisme pada Materi segitiga dikelas II SMP layak digunakan dengan revisi, sehingga media pembelajaran yang dikembangkan dinyatakan valid. Hal ini sesuai dengan pendapat Nieven (dalam Rochmad, 2012) bahwa media pembelajaran dikatakan valid jika validator menyatakan bahwa perangkat pembelajaran layak digunakan dengan atau tanpa revisi.

Setelah dilakukan validasi oleh para ahli terhadap macromedia flash 8 Berbasis konstruktivisme pada Materi segitiga. Pertama dilakukan uji coba perorangan yakni uji coba dengan guru mata pelajaran matematika kelas VII SMP. Uji coba perorangan dilakukan dengan memberikan media dan angket kepada guru mata pelajaran matematika kelas VII SMP. Angket dan media diberikan kepada guru matematika kelas VII SMP. Setelah dilakukan uji coba perorangan didapatkan hasil media layak digunakan.

Kemudian dilakukan uji coba kelompok kecil yakni uji coba dengan 8 orang siswa kelas VII SMP. Uji coba kelompok kecil dilakukan dengan memberikan media dan angket kepada siswa. Sebelum uji coba kelompok kecil, dilakukan validasi instrumen angket uji coba kelompok kecil oleh dosen pendidikan matematika Universitas Jambi. Hasil validasi instrumen angket uji coba kelompok kecil dan uji coba kelompok besar yakni didapatkan kriteria cukup valid. Angket dan media komik diberikan kepada 8 orang 
siswa kelas VII SMP. Setelah dilakukan uji coba kelompok kecil didapatkan hasil dengan kriteria sangat praktis.

Setelah dilakukan uji coba kelompok kecil, kemudian dilakukan uji coba kelompok besar yakni uji coba dengan satu kelas yakni kelas VII SMP. Uji coba kelompok besar dilakukan dengan memberikan media dan angket kepada siswa kelas VII SMP. Setelah dilakukan uji coba kelompok besar, didapatkan hasil dengan kriteria sangat praktis.

Hal ini sesuai dengan pendapat Menurut Nieven (dalam Rochmad, 2012) bahwa media pembelajaran dikatakan praktis jika guru dan siswa mempertimbangkan perangkat pembelajaran mudah digunakan dilapangan dan sesuai dengan rencana perancangan peneliti. Media pembelajaran dikatakan praktis jika para responden (dalam hal ini adalah guru dan siswa) memberikan respon positif dan menyatakan perangkat pembelajaran dapat digunakan dalam pembelajaran, ditunjukkan oleh angket atau kuisioner (apresiasi) yang diisi oleh guru dan siswa. Berdasarkan penjelasan diatas dimana guru dan siswa memberikan respon positif dan menyatakan bahwa media mudah digunakan dalam pembelajaran maka media macromedia flash 8 Berbasis konstruktivisme pada Materi segitiga telah memenuhi semua indikator kepraktisan dan dinyatakan praktis.

Setelah siswa selesai melihat macromedia flash 8 Berbasis konstruktivisme pada Materi segitiga, maka dilakukan tes hasil belajar kepada siswa kelas VII SMP. Sebelum dilakukan tes hasil belajar, terlebih dahulu instrumen tes hasil belajar dilakukan analisis validitas. Validitas yang dilakukan yakni validitas instrumen.

Setelah dilakukan uji coba tes hasil belajar kepada siswa kelas VII SMP, didapatkan hasil bahwa Kriteria ketuntasan minimal (KKM) yang berlaku di kelas VII SMP. Sehingga nilai siswa yang dibawah 76 dinyatakan tidak tuntas. Sehingga terdapat 17 orang siswa yang tuntas dan 3 orang siswa yang tidak tuntas. Adapun persentase ketuntasan yang didapat yakni $85 \%$ dengan kriteria sangat efektif. Suatu media dikatakan efektif apabila siswa berhasil dalam proses pembelajaran dan terdapat kekonsistensian antara kurikulum, pengalaman belajar siswa dan pencapaian proses pembelajaran yang dilihat dari hasil belajar siswa.

Dengan demikian, macromedia flash 8 Berbasis konstruktivisme pada Materi segitiga memiliki kualitas yang baik karena telah memenuhi aspek-aspek kualitas media menurut Menurut Nieven (dalam Rochmad, 2012) yaitu valid, praktis dan efektif.

Hasil uji coba perorangan yakni media layak diujicobakan Pada saat penilaian oleh guru mata pelajaran matematika, terdapat beberapa komentar dan saran yang diberikan. Adapun komentar dan saran yang diberikan untuk media macromedia flash 8 berbasis konstruktivisme ini yakni untuk lebih mengawasi siswa di saat pembelajaran agar siswa tidak main-main saat pembelajaran.

\section{KESIMPULAN}

Dari hasil penelitian yang dilakukan peneliti di SMP di kota Jambi pada mata pelajaran segitiga yaitu mengembangkan sebuah produk Multimedia Pembelajaran Menggunakan Media Flash materi segitga 
Pengembangan Media Pembelajaran Matematika Berbasis Konstruktivisme pada Materi Segitiga Siswa Kelas VII SMP, Elsi Indria Sari, Nizlel Huda, Syamsurizal

untuk siswa kelas VII SMP/MTs, bahwa multimedia pembelajaran yang dikembangkan dinyatakan layak digunakan oleh validator. Multimedia pembelajaran yang dihasilkan juga dinyatakan sudah praktis dan Multimedia pembelajaran yang dihasilkan juga dinyatakan efektif sehingga layak untuk digunakan.

Berdasarkan hasil penelitian di SMP Kota Jambi, bahwa produk yang dihasilkan layak digunakan dan praktis, berdasarkan hasil uji coba produk di SMP dan sebelumnya telah di validasi terlebih dahulu oleh pakar yang sesuai dengan bidangnya masing-masing, sehingga multimedia pembelajaran dapat digunakan sebagai media pembelajaran dalam proses pembelajaran.

\section{UCAPAN TERIMA KASIH}

Ucapan terimakasih dan syukur kepada Tuhan yang maha Esa, kepada kedua orang tua serta keluarga dan sahabat yang sudah mendukung serta mendoakan selama ini, mampu bertahan karena dukungan kalian, semoga kedepannya selalu baik dan dipermudah

\section{REFERENSI}

Adisusilo, S. (2012). Pembelajaran Nilai-Nilai Karakter Konstruktivisme dan VCT Sebagai Inovasi Pendekatan Pembelajaran Afektif. PT Rajagrafindo Persada.

Anggra. (2008). Memahami Teknik Dasar Pembuatan Game Berbasis Flash (G. Media (ed.)).

Ariesto, H. (2008). Teknologi Informasi dan Komunikasi dalam Pendidikan. Graha Ilmu.

Arsyad. (2011). Media Pembelajaran. Raja Grafindo Persada.

Barlia, L. (2010). Elementary School Teacher Personality in Students' Learning Motivation in Science. Jurnal Cakrawala Pendidikan, 29(1).

Borg \& Gall (1983). Educational Research: An Introduction,Fifth Edition. Longman.

Driver, R., \& Oldham, V. (1986). Constructivist Approach to Curriculum Development in Science. Studies in Science Education, 13.

Glasersfeld, \& Von, E. (1990). Environment and Communication. In International Perspectives, (Steffe In). Lawrence Erlbaum.

Kukla, A. (2003). Konstruktivisme Sosial dan Filsafat Ilmu. Jendela.

Lerman, S. (1988). Constructivism, Mathematics, and Mathematics Education. Journal of Educational Studies in Mathematics, 20.

Priyanto. (2017). Pengolah Citra Digital: Teori dan Aplikasi Nyata. Informatika.

Purwanto. (2004). Psikologi Pendidikan. Remaja Rosdakarya.

Rochmad. (2012). Desain Model Pengembangan Perangkat Pembelajaran Matematika. Jurnal Kreano, 3. https://journal.unnes.ac.id/nju/index.php/kreano/article/view/2613/2672

Rusdi. (2018). Penelitian Desain dan Pengembangan Kependidikan. Raja Grafindo Persada.

Sugiyono. (2017). Penelitian Pendidikan. Alfabeta.

Thiagarajan, S., \& Et.al. (1974). Instructional Development For Training Teachers of Exceptional Children. Indiana University Bloomington. 
Trianto. (2009). Mendesain Model Pembelajaran Inovatif, Progresif dan Kontekstual. Kencana Prenanda Media Group.

Wheatley. (1991). Constructivist Perspectives on Science and Mathematics Learning. Journal of Science Education, 75(2).

Yudhiantoro. (2003). Panduan Lengkap Macromedia Flash 8. Andi Offset. 